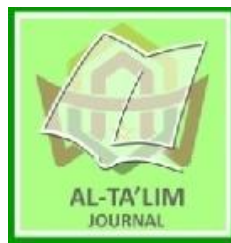

AL-TA'LIM JOURNAL, 27 (2), 2020, (127-139)

(Print ISSN 1410-7546 Online ISSN 2355-7893)

Available online at http://journal.tarbiyahiainib.ac.id/index.php/attalim

\title{
Empowering Education: Exploring Teachers' Classroom Practices in Vocational Schools
}

Received: $16^{\text {th }}$ May 2020; Revised: $15^{\text {th }}$ April 2020; Accepted: $30^{\text {th }}$ June 2020

Permalink/DOI: http://dx.doi.org/10.15548/jt.v27i2.628

\section{Teuku Zulfikar *)}

Universitas Islam Negeri Ar-Raniry Banda Aceh, Indonesia.

E-mail: teuku.zulfikar@ar-raniry.ac.id

\section{Emawati}

Universitas Muhammadiyah Aceh

E-mail: emawati@unmuha.ac.id

\section{Hidayat Al Azmi}

Universitas Islam Negeri Imam Bonjol

Padang

E-mail: hidayatalazmi@gmail.com

\section{*) Corresponding Author}

\begin{abstract}
Teaching is indeed a complex provision, which requires teachers being competent in many respects. They should be very knowledgeable in subjects they teach; they should also acquire skills in transferring their subject matters; they need to be skillful in classroom management, and are capable of designing and developing teaching materials. For that reason, teachers should always engage in professional development to guarantee their best performance. Understanding teachers' ways of classroom practices is the first step for teachers' professional development. Therefore, it is timely to conduct a classroom research to explore teachers' performance, and thus this research explored teachers' classroom practices in six vocational schools in Aceh. The data were collected mainly through observation of the instructional process in the classroom and in the workshop. The research found that some teachers are capable of transferring knowledge effectively through various teaching strategies; some of them are capable of engaging students into effective learning. However, the findings also suggest ineffective classroom practices, in which teachers fail to perform well, which leads to ineffective learning.
\end{abstract}

Keywords: Teachers' competence; pedagogical content knowledge; classroom practices; teachers' attitudes; teaching skills.

How to Cite: Zulfikar, T., Emawati, E., \& Al-Azmi, H. (2020). Empowering Education: Exploring Teachers' Classroom Practices in Vocational Schools. Al-Ta lim Journal, 27(2). doi:https://doi.org/10.15548/jt.v27i2.628

\section{INTRODUCTION}

Teaching is a complex profession (Livingston, 2017); it requires sufficient knowledge, competences, skills, and attitudes to succeed in teaching and help students to better learn (Darling-Hammond, 2017). It is important to note that all teachers are required to acquire all these components to be professional teachers. In general sense, these components are used interchangeably although they bear different meaning upon looking into more details.

Teachers' Knowledge is seen a theoretical and practical understanding on something. It is teachers' ability to know something and transfer information about something. Teachers should assure themselves to have sufficient knowledge on what they wish to teach referring to subject matter knowledge. The other kind of knowledge is known as pedagogical content knowledge (PCK), which refers to the ability of teachers to transfer content of the subject matter effectively. Teachers have to obtained knowledge on strategies of classroom management; on learning and learners' characteristics; on educational contexts; on educational objectives; on content; on 
curriculum; and on professional knowledge (Hakansson, 2015).

In addition, teachers' competences are defined as the combination abilities of knowledge and skills. There are four competences required for all teachers to have: personal, professional, pedagogical, and social competences. These competences are expected to enable teachers to succeed in their teaching. These four competences are interrelated and they are attributes of effective teachers. Teachers' personalities are very much important to succeed in teaching (Göncz, 2017). In addition to having good personalities, teachers should also be professional in their job (Amin \& Saukah, 2015), and their professionalism has to be developed consistently (Vangrieken, Meredith, Packer \& Kyndt, 2017). The pedagogical competence is also important for effective teaching (Suciu \& Lmâ ă, 2011), Liakopoulou (2011), for example stated that in fact pedagogical competence is a prerequisite for entering the teaching profession. The other competence equally important in teaching is the social competence. This allows particular teachers to interact with other effectively (Hakim, 2015; Brophy-Herb, Lee, Nievar, Stollak, 2007).

Teachers' skills are also important for successful teaching. Skills are something trained. They are not innate behavior, and thus they are only improved through practices. Teachers' skills include among others are teaching skill and classroom management skills. To enable teachers teach well and manage their classroom effectively, they should join some trainings to enable them teaching skillfully. The other important components needed for effective teaching. Teachers' attitude is a degree that they have a certain attributes that allow them to engage with students in good manner (Aliakbari \& Heidarzadi, 2015; Hakansson, 2015).

As the teacher is a central part for successful learning, it is important to note that to empower education, policymakers should empower teachers and they should not left behind. There are many ways to empower teachers, one of which is through teacher professional development program (Soini, Pietarinen \& Pyhältö, 2016). Nevertheless, prior to empowering teachers, it is important to observe their classroom performance to identify their teaching skills. Only by so doing, policymakers are able to identify teachers' competences, and then teacher professional development program can be conducted (Aimah, Ifadah, \& Bharati, 2017).

Research on classroom practices has been conducted by many. For example, Soslau, Gallo-Fox, and Scantlebury (2019) studied the effectiveness of co-teaching among student-teachers. The study found that co-teaching supports learning and help adaptive teaching expertise. Other study by Soinia, Pietarinenb and Pyhältöc (2016) explore teachers' active engagement in professional learning during their classroom practices. The study found that teachers' reflective practices during teaching becomes a catalyst for professional development. The teachers are also found to have learnt to improve their own practices while teaching. In addition, Aliakbari and Heidarzadi (2015) explore the relationship between teachers' teaching beliefs and teaching practices. The study found significant relationship between teaching beliefs and their actual classroom practices. Other studies regarding classroom practices can also be referred to studies by Leavitt (2013); Håkansson (2015); Bledsoe \& Baskin (2014); Putney and Frank (2008); and Jones, Holmes, Macrae, \& Maclure, (2010). These all studies however, are different in their nature from this current work, in which our study focuses on grounded data regarding vocational school teachers' classroom practices to generate attributes of teachers and their practices.

As understanding teachers' performance is important for empowering education, this research is significant in the attempt to unveil teachers' classroom performances. The findings of the study provide important steps to improve quality of education in the future. To start our inquiry, we would ask the following research questions: How do teachers begin their instruction? What strategies do they take in 
managing their teaching effectively? And what are teachers' attributes in particular vocational schools in Aceh. These questions were answered through the classroom research.

\section{METHOD}

Much of social research, especially in educational context has been severely criticized for it too far removed from teachers and learners' immediate concerns. This leads to paradigm shift in conducting educational research, and thus contemporary educational research focuses on interaction between teachers and learners, and also between learners and learners and identify students' immediate needs (Jenkins, Breen, Lindsay, Brew, 2012; Moore, 2000). This study is then known as classroom research. In this context, classroom is defined as wide ranges of learning context, in which teachers-learners and learners-learners interact in the context of learning. Classroom is then referred to classes where instruction takes place, 'multi-media lab, distance learning situations, one-to-one tutoring' and other places within a particular school building where learning process is feasible.

This classroom research was conducted through a small-scale ethnographic study. As McKay (2008) suggests that classroom research consists of several types of methodologies-among others are action, introspective, case and also ethnographic studies. For the purpose of this research, we conducted a small-scale ethnographic studythis refers to the small scope of the study itself. This study did not intend to interpret certain conditions in a given large cultural context as normally conducted by ethnographers (Hammersley, 2006); it rather explored a small culture within classroom contexts (Putney \& Rank, 2008) in particular six vocational schools across Aceh.

In addition, ethnographic study is conducted through emic, etic perspectives and holistic views. Emic perspective refers to researchers' attempt to understand the insider view of the participants (Putney \& Rank,
2008; Zulfikar, 2014). For example, in this particular research, we observed instructional process in a classroom. By contrast, etic perspective means we were the ones who interpret classroom phenomenon. We observed research sites holistically, in which we focused on what people say in a given context and across contexts to arrive at comprehensive understanding on the phenomenon.

In collecting data for this project, we visited six vocational schools, and we first secured the permission to enter the classroom and observe instructional process in year 11 for four days (Monday-Friday). The observation focused on teacher-learners interaction and also interactions among learners. We focused mainly on teachers' ways of delivering subject matters; their ways of posing questions to students as well as responding to students' questions. We also focused on teachers' ways of correcting students' mistakes. Basically, we recorded thoroughly events taking place during instruction. In addition to observing teachers' ways of teaching, we also visited workshop, in which students engaged in learning practicum. We also observed how teachers provided assistantship to students during their practicum process and other instructional process therein.

The data was analyzed through grounded theory method, in which coding techniques was used-'classifying or categorizing individual pieces of data' (Babbie, 2008, p. 422; Babbie, 2016; Gibb, 2018; Glesne, 2015; Silverman, 2020). We also referred to strategies used by Putney and Rank (2008). We analyzed observation fieldnotes through coding techniques referring to Silverman's (2020) strategies. First, we used open coding-we first examined the data and classified them into several codes, in which we drew from the data; the data was broken down into several parts. These parts were examined for similarities and differences, which later on they were grouped into certain categories. Second, we then used axial coding technique in which the data under categories were re-examined and re-grouped. Finally, we 
used selective coding, in which central concept was selected after the analysis of open and axial coding.

\section{Research Procedures}

In collecting the data, we used two instruments in collecting the data. The first instrument was the observation sheet. The sheet contains headings to guide their observation. We did not use pre-designed observation checklists as we did not intend to test any theory; it rather generates new theories out of our observation (see Jones, Holmes, Macrae, \& Maclud, 2010). Hopkins (2008), for example suggests that in conducting classroom research, researchers do not need to start with a 'problem', what all they need is only a general idea that there is something to be improved. Therefore researchers need to only focus on what is happening in the classroom? Is there anything problematic taking place in the classroom? And can I do anything about it? These are concerns that researchers need to start their inquiry with (Hopkins, 2008). Researchers may also take note on 'a particular issue or teaching behavior over a period of time; ... reflect general impressions of the classroom and its climate' (Hopkins, 2008, p. 105; Taber, 2007).

\section{Research sites and participants}

Six vocational schools were purposively chosen across the Province of Aceh. The schools selected were located in rather similar demography. We selected Year 11 in each school as the research site, in which students and teachers teaching in Year 11 was recruited as research participants.

\section{RESULT AND DISCUSSION}

\section{The Teachers}

In all educational settings, teachers play important roles since they determine educational quality. For this very reason, competent teachers are required to produce qualified students (Kapalka, 2009). This classroom research was conducted to examine teachers' ways of teaching in six vocational schools in Aceh. It is important to explore and review teachers' classroom practices to obtain a clear picture on instructional process. All attempts to reform school system have to start from understanding what takes place in classrooms. It is for this reason that an effort to picture teachers' classroom practices is necessary (Aimah, Ifadah, Bharati, 2017).

There were approximately 27 productive teachers involved in this classroom research. These teachers were observed to identify how they ran their instruction, it examined instructional process took place in classroom within these six schools. The observation revealed detailed description of instructional process, the way teachers started classes and their ways of teaching. Some categorizations of teachers had been made to vividly describe teachers' ways of teaching.

\section{Beginning Instruction}

Our research found that there were three ways of opening the lesson found during the observation: close, fluid boundaries and reviews of previous lesson.

\section{Close and Fluid Boundaries}

Close boundaries refer to formal ways of opening the lessons, in which teachers distribute syllabus; set classroom code of conduct, in terms of late students, assessment procedure, and sorts of materials used in the classroom throughout academic years (Aliakbari \& Bozorfmanesh, 2015; Woodward, 2001). Twelve teachers observed engaged in close boundaries, in which they set the goal of the lesson at the first meeting as well as describe classroom code of conduct. For example, a teacher in a particular school was found to call students' names prior to engaging in formal instruction. Having called students' name, he set the classroom regulations such as dress code and types of interaction permissible during instruction. In addition, teachers invited students to recite prayers prior to teaching. This practice took place in many schools observed, especially in classroom, in which these 12 productive teachers teach. 
The other teachers seemed to start the lesson informally, which is known as the fluid boundaries. In fluid boundaries, teachers do not set classroom code of conduct, do not check students' attendance and do not set the aim of the lesson (Woodward, 2001). For example, in some schools, productive teachers did not check students' attendance; they in fact spent a very short time in the classroom. They would rather invite students directly to the workshops or to the field in case of Art and Sport subjects.

\section{Reviews of the lesson}

Reviews of previous lesson are important to link lessons being taught with the previous ones. Integrating the subjects learned by students is considered of high value, since it portrays comprehensively what subject students learn and why they do so. Some productive teachers observed reviewed previous lessons, while others chose not to do so. Teachers who reviewed the lesson believe that students' understanding of the lesson is significant for successful learning. They argued that only after students understood the lesson completely do teachers continue teaching other topics within a particular subject. However, some teachers do not share this idea. They in fact believed that there is no need to review what have been learnt. Some of these teachers believed that students should make sure themselves that they have learnt and understood the subject well.

\section{The Instruction}

Classroom observation uncovered various attributes of productive teachers in six vocational schools in Aceh. In the report, four groups of productive teachers were identified.

\section{Absent, Hesitant, and Reactive Teachers}

Absent, hesitant and reactive teachers refer to those who did not interact with their students; they were hesitant to interact and engage in instructional process. For example, a teacher in School A was seen as an absent teacher. During instruction, he usually sat in his own seat and taught while sitting. In addition, he usually asked questions and responded to students' questions from afar. The teacher was also absent in controlling classroom dynamic. Students often sat in group, but they seemed not to engage in learning process. This was because teacher was not active in managing and controlling what happened in the class.

The other teacher from School B was also seen as an absent teacher. Like the other teacher, this teacher usually sat back and was relax in his own seat. During teaching, this teacher tended to use instructional media, such as video and overhead projector. In the video, he usually showed a short film on how an engine was operated. This practice was seen effective in the view of instructional process. However, in showing the video, the teacher did not engage deeply with students. He did not guide students and explain to them what they were actually watching.

Being absent during teaching does not only reduce learning enthusiasm but also distract learning focus. When teachers for example do not engage in teaching, students' anxiety in learning tends to reduce significantly. Effective teachers are encouraged to communicate actively with students. This was important because the failure to engage actively with students would result in communication breakdown, and this breakdown would in turn inhibited learning progress.

A teacher in School F was found to be hesitant. She was a hesitant teacher because she was not well-engaged in what she taught. She seemed to be reluctant and in fact lack of self-efficacy. This can be observed from her teaching style, in which she came to class, sat in her chair reluctantly and then assigned a student to dictate the lesson to other students. While an assigned student dictated learning materials out of a textbook, the teacher left the classroom and did not return until before the class ended.

The observation also found that there were some reactive teachers, meaning that 
they tended to get angry when students made noise and mistakes. This kind of teachers seemed to be inconsiderate, in which they failed to understand students' problems. They reacted negatively when students failed to finish homework; they also reacted negatively when they could not control the class. Being inconsiderate toward students would not only shut them down from communicating but also would reduce student' creativity. Students were afraid to make mistakes, which then resulted in their unwillingness to participate in learning process.

\section{Creative, Interactive, and Democratic Teachers}

While some teachers were found to be absent, hesitant and reactive, many teachers in these six schools were creative, interactive and also democratic. A teacher in School A, for example was found to be very interactive. This could be seen from his teaching styles. $\mathrm{He}$ was very articulate in conducing classroom activities; his explanation was clear and straight forward. His perfect tone of voice also increased the clarity of his message. In addition, the teacher was very interactive, in which he was fully engaged in the teaching process. For example, he often asked students a question, and then invited other students to comment. This kind of cooperative learning may boosts students' self-esteem and most likely to improve their academic achievement.

Other teachers from a school in School B seemed to be creative and democratic in their teaching. Creativity is required by all teachers to promote good learning atmosphere. Teachers should be creative in their teaching styles, materials given and also in their ways of assessing students' achievement. Teachers are encouraged to have both pedagogical content knowledge and subject matter competent. This classroom research found that two teachers in School B took advantage of the availability of teaching media, such as PowerPoint to explain about engines and how to operate them. One teacher at the school, for example designed materials in PowerPoint and showed them in the classroom.
In addition, he also explained the way, in which a particular engine worked through video. This developed students' enthusiasm to learn and develop their understanding on a particular lesson. The other teacher at the school seemed to encourage students' participation. He usually interacted with students, asked those questions, and also responded to their inquiries. In addition, like his colleague at school, he was very articulate in presenting the lesson, and thus students were able to grasp information easily.

Effective classroom practices were also found in School F. Three teachers were found to have been very interactive and democratic in their teaching. Their willingness to approach students individually and help students solve their problem was indicative of their democratic teaching style. When students made mistakes in the classroom, these teachers did not judge them; rather they corrected their mistakes and provided them solution. In teaching these teachers gave spaces to students to express opinions and seek answers independently. Three teachers at School D were also reported to be interactive and democratic. These teachers approach teaching through problem posing strategy. This strategy has been popular because it enables students to be active and to be knowledge seekers. When teaching, these three teachers usually asked provocative questions. Asking this kind of question is typical problem posing strategy. To answer questions, students need to think critically and discuss with classmates. This kind of classroom practice allowed students to think critically and solve problems individually, while teachers acted as facilitators.

In addition, a teacher at School E shared similar attributes to the above six teachers. The teacher at the school promoted dialogue education, in which they interacted with students and developed dialogue with students. Dialogic education is important in boosting students' academic achievement. This is because knowledge is created through dialogue between teachers and students. To make dialogue possible, teachers should show 
love, humility and faith to their students. The existence of love, humility and faith allowed horizontal and mutual trust communication to take place

\section{Intelligent, Smart, and well-prepared Teachers}

The classroom research also found positive attributes of productive teachers in some vocational schools in Aceh. Some teachers in School B were seen to be intelligent, smart and well prepared. These teachers were described as intelligent because they were qualified enough in subject matters; they acquired in-depth knowledge in subject they were teaching. These teachers were also smart, in which they managed and controlled classroom dynamic effectively. They seemed to understand when to speed up and to slow down in their classroom instruction. For example, when teaching a particular subject, they tended to explain it briefly, while on the other instances, they seemed to slow down their explanation. This indicates their astuteness in teaching. These teachers were also seen as well-prepared teachers. This was indicative from their materials designed for teaching. Before teaching, they usually printed learning materials and distributed them to students. They also prepared learning media, such as movies, materials in PowerPoint, Modules and textbooks. This attribute was also found in a teacher at School D.

In addition, a large number of productive teachers in School F were smart and intelligent. Some of these teachers were able to provide detailed answer to students' questions. They were technology savvy, in which they used instructional media effectively. In addition, some teachers at the school engaged in mentorship. They did not treat their students as learners per se but as their mentees. Good relationship between mentors and mentees enhanced the possibility for effective learning. Students learned best when they were regarded as mentees, and their teachers as mentors. In addition, some teachers in the school taught subjects deductively, from basic skill to advance one. For example, prior to sending students to workshop, they made sure that students had been equipped with good knowledge on theoretical basis. Only after students acquired sufficient knowledge on certain topic did teachers ask them to do practicum in the workshop.

\section{Authoritative, Dominated, and Withdrawn Teachers}

The research also revealed 'negative' attributes of some teachers in vocational schools in Aceh. Two teachers at School B were withdrawn, while one of them was a dominated teacher. These kinds of teachers were found in all schools observed. Withdrawn teachers referred to those who were not interested to take part in classroom discussion; they also did not pay attention if students have understood the lesson. The teachers also withdrew themselves from important activities that students needed to engage in real life situation. In addition, dominated teachers were those who dominated the class, engaged in teachertalked strategy and also ignored the need of students to express ideas. Autocratic teachers referred to those who did not allow students' mistake. This kind of teacher tended to ignore students' need to exercise their innate capabilities in the classroom.

At least two teachers at School B and one at School E were seen as withdrawn. Teachers were not articulate, in which they spoke too slow and low tone of voice. This made students bored and lost interest in following the lesson. In addition, teachers withdrew themselves from the need to understand if students have understood the lessons. Like his counterpart at School B, a teacher from School E did not invite students to farm to feel real life experience. Other teachers at School B, School E and School F were dominated teachers. They were dominated because they used lecturing technique in teaching and gave little space for students to participate. Some teachers in this 
group only taught out of textbooks and relied very much on these textbooks.

In addition, two teachers in School F were autocratic. They were so because they only asked students to take note on learning materials. Having taken notes on particular subjects, they explained the subject briefly. In this classroom atmosphere, students' voice left unheard, in which they were considered as incapable at giving opinions.

This classroom research has revealed various teachers' attributes; this is so because teachers bring their own styles into teaching (Shindler, 2010). Some productive teachers were found to have multiple attributes. In some instances, teachers may be smart and intelligent. Teachers should be smart enough not only in the cognitive domain, in which they acquire sufficient subject matter knowledge but also in the affective domain, for example, they should maintain their emotion, in which they should learn to hold their tongue and are patient during the instructional process (Ridnouer, 2016). For that reason, teachers should always monitor their classroom language (Moore, 2000). In addition, teachers should be smart enough to engage their students in learning because it will facilitate students' self-construction of knowledge (Arrazola \& Bozalongo, 2014; Leach, 2018; Kapalka, 2009; Tauber, 2007). This is important because the nature of learning is transformative, in which students construct their own knowledge actively as facilitated by their teachers (Jenkins, Breen, Lindsay, \& Brew, 20121 Moore, 200; Shindler, 2010). However, engaging students into active learning is complicated, since students also come to classroom bringing their multiple attributes, some of them are fear of making mistakes, fear of being laughed at; and some of them just do not feel comfortable communicating in the classroom. For that reason, Bledsoe and Baskin (2014) argued that teachers should overcome students fear by listening to them (Leach, 2018) and taking care of the classroom atmosphere (Leaitt, 2013); and balancing and varying teaching styles (Hakansson, 2015).
In addition, some teachers were found to be absent and in fact withdrawn from instructional process. This is so because teaching is a tricky business. In fact, Hollins, Luna and Lopez (2014) argue that teacher education program per se may not be related to teachers' competence; it is the training, the reflection on teaching, constant engagement in professional development will guarantee teaching effectiveness (Ab Rashid, 2018; Korkko, Kyro-Ammala, Turunen, 2016; Larrivee ,2000). Engaging in professional development is a must for all teachers, since it helps them empower themselves (Alibakhshi \& Dehvari, 2015; Louwsa, Veen, Meirina \& Driel, 2017; Tabatabaee-Yazdi1, Motallebzadeh, Ashraf \& Baghaei, 2018). However, not all teachers are reflective; some of them resist changing and reforming, and thus they cannot improve their classroom practices.

The teachers in these six schools were grouped into four categories: absent, hesitant and reactive teachers; creative, interactive and democratic teachers; smart, intelligent and well-prepared teachers; and autocratic, dominated and withdrawn teachers. These different groups were categorized based on their attributes. Some teachers, for example were considered as absent, hesitant and reactive teachers because of their attributes showing that they were absent, hesitant and also reactive during instructional process. Other teachers in the second, third and fourth group were regarded as so due to the fact that they reflected those characteristics during their classroom practices.

Teachers' ways of teaching were influenced by multiple factors, which then shape their identity, such as students' attributes, classroom facilities, financial resources and demography (Devine, Fahie \& McGillicuddy, 2013; Stolle \& FrambaughKritzer, 2014) were all significant in shaping teachers' ways of being in the classroom (Bower \& Parsons, 2016). Some teachers in high achieving schools, such as School F and School A were revealed to have engaged in effective classroom practices. However, critical questions emerge on what make them 
teach well. Is it because of teachers themselves were capable of teaching, or the fact that students in these school were capable of learning, in which they are already smart and intelligent from the first place. While in low achieving schools, teaching condition might be so much different in terms of facilities, students' learning passion, textbooks, and also instructional media. In fact, oftentimes, students' expectations and those of schools tend to be mismatching (Lupton \& Hempel-Jorgensen, 2012; Maden 2001; Mills \& Gale 2009; Carrasco-Rozas 2010; Ofsted 2000; Smyth \& McInerney 2007; Thomson 2002).

In addition, teachers' ways of teaching were also influenced by learning facilities, such as teaching media, spaces for practicum and also sophisticated library are important to trigger teachers as well as students' learning motivation. Schools which do not equip themselves with sufficient learning facilities will result in teachers' lack of teaching motivation, which in turns influence students' ways of learning. It is important to note that teachers' approaches are indeed related so much to students' ways of learning (Beausaert, Segers \& Wiltink, 2013; Trigwell et al. 1998; Trigwell, Prosser, \& Waterhouse 1999; Kember \& Gow 1994).

\section{CONCLUSION RECOMMENDATION}

AND

This study has given insights on attributes of particular teachers in certain vocational schools in Aceh. It showed multiple ways of beginning the lesson. Some teachers seemed to be very organized, in a way they prepared set of learning, teaching materials and also teaching scenarios. Some others were shown to be more relaxed and flexible in their ways of starting the lesson. They did not approach teaching the way the other types of teachers have engaged with. The other way of starting the lesson as found in the study was through reviewing previous lesson. This particular activity was implemented as those teachers believed on the need to review previous lesson to students as it allowed students to recall their memory on particular subjects learned.

The study also found that some teachers used certain strategies, such as using video to show certain lesson, such as videos on how certain product was constructed. The vivid images shown in the video allow students to learn better. The other strategy, teachers used was the power-point, in which teachers showed students certain procedures in constructing particular products.

This research also unveiled certain attributes of teachers. Some teachers were found to be autocratic, were hesitant, absent, and withdrawn during the teaching. Other teachers were identified as intelligent, smart and well-prepared. In some schools, teachers were also found to be democratic, active and creative. These different attributes may be the result of their own personality, and some due to external factors that shapes certain teachers' attributes.

\section{REFERENCES}

Aimah, S., Ifadah, M., Bharati, D. A. L. (2017). Building Teacher's Pedagogical Competence and Teaching Improvement through Lesson Study (2017). Arab World English Journal (AWEJ), 8(1), 66-78 DOI: https://dx.doi.org/10.24093/awej/vol8 no1.6

Aliakbari, M. \& Bozorgmanesh, B. (2015). Assertive classroom management strategies and students' performance: The case of EFL classroom. Cogent Education, $\quad 2$ : 1012899 ; http://dx.doi.org/10.1080/2331186X.2 015.1012899

Aliakbari, M. \& Heidarzadi,. M. (2015). The relationship between EFL teachers' beliefs and actual practices of classroom management. Cogent Education, $\quad 2$ : 1039255 http://dx.doi.org/10.1080/2331186X.2 015.1039255 
Alibakhshi, G., \& Dehvari, N. (2015). EFL Teachers' Perceptions of Continuing Professional Development: A Case of Iranian High School Teachers. PROFILE, 17(2), 29-42

Amin, M., \& Saukah, A. (2015). Factors Contributing to EFL Teachers' Professional Development in Indonesia. Excellence in Higher Education, 6, 12-20

Arrazola, B. V., \& Bozalongo, J. S. (2014) Teaching practices and teachers' perceptions of group creative practices in inclusive rural schools, Ethnography and Education, 9(3), 253-269, DOI: $10.1080 / 17457823.2014 .881721$

Segall, A. (2004). Revisiting pedagogical content knowledge: the pedagogy of content/the content of pedagogy. Teaching and Teacher Education 20, 489-504

Babbie, E. (2008). The basic of social research. 4th ed. Belmont, CA: Thomson Wadsworth

Babbie, E. (2016). The basic of social research. The 7th ed. Boston: Cengage Learning

Blašková, M., Blaškoa, R., Kucharcíková, A. (2014). Competences and Competence Model of University Teachers. Procedia - Social and Behavioral Sciences, 159, 457 - 467

Bledsoe, S. T., \& Baskin, J. J. (2014) Recognizing Student Fear: The Elephant in the Classroom. College Teaching, 62 (1), 32-41, DOI: 10.1080/87567555.2013.831022

Boeije, H. (2010). Analysis in qualitative research. Los Angeles, CA: Sage

Bower, H. A., \& Parsons, E. R. C. (2016) Teacher Identity and Reform: Intersections Within School Culture. Urban Rev, 48, 743-765, DOI 10.1007/s11256-016-0376-7
Brophy-Herb. H. E , Robert E. L., Angela N. M., Stollak, G. (2007) Preschoolers' social competence: Relations to family characteristics, teacher behaviors and classroom climate. Journal of Applied Developmental Psychology, 28, 134-148

Carrasco-Rozas, A. 2010. A case-study of the Chilean policy agenda for disadvantaged primary schools: Meeting their challenges. $\mathrm{PhD}$ Thesis, University of Cambridge

Creswell, J.W. (2014). Research design: qualitative, quantitative, and mixed methods approaches. Los Angeles, London, New Delhi, Sage Publication.

Darling-Hammond, L. (2017) Teacher education around the world: What can we learn from international practice? European Journal of Teacher Education, 40(3), 291-309, DOI: 10.1080/02619768.2017.1315399

Devine, D., Fahie, D., \& McGillicuddy, D. (2013) What is 'good' teaching? Teacher beliefs and practices about their teaching, Irish Educational Studies, 32(1), 83-108, DOI: 10.1080/03323315.2013.773228

Gibb, G. R. (2018). Analysing qualitative data. The 2nd ed. Los Angeles, London, New Delhi, Sage Publication, 2018.

Glesne, C. (2015). Becoming qualitative researchers, the 5th edition, New York and Boston: Pearson

Glesne, C. (2006). Becoming Qualitative researchers. New York and Boston: Pearson

Göncz, L. (2017) Teacher personality: a review of psychological research and guidelines for a more comprehensive theory in educational psychology, Open Review of Educational Research, 4(1), 75-95, 
DOI:

$10.1080 / 23265507.2017 .1339572$

Håkansson, J. (2015) Structured teaching and classroom management: the solution for the decline of Swedish school results? Conclusions drawn from a comparative meta- synthesis of teaching and learning. Teachers and Teaching, 21(5), 584-602, DOI: $10.1080 / 13540602.2014 .995479$

Hakim, A. (2015). Contribution of Competence Teacher (Pedagogical, Personality, Professional

Competence and Social) On the Performance of Learning. The International Journal of Engineering and Science (IJES), 4(2), 01-12.

Hammersley, M. (2006). Ethnography: Problems and prospects. Ethnography and Education.

1(1), 3-14

Hopkins, D. (2008). A teacher's guide to classroom research, 4th ed. New York: Open University Press

Jenkins, A., Breen, R., Lindsay, R., \& Brew, A. (2012). Reshaping teaching in higher education linking teaching with research. London and Sterling: Kogan Page Limited

Jones, L., Holmes, R., Macrae, C., \& Maclure, M. (2010). Documenting classroom life: how can I write about what I am seeing? Qualitative Research, 10, $479 . \quad$ DOI: $10.1177 / 1468794110366814$

Kapalka, G. (2009). Teachers of challenging students. Thousand Oaks \& London. Corwin- Sage Publication

Kember, D., \& Gow, L. (1994). Orientations to teaching and their effect on the quality of student learning. Journal of Higher Education 65: 5874.

Korkko, M., Kyro-Ammala, O.,Turunen, T. (2016) Professional development through reflection in teacher education. Teaching and Teacher Education, 55, 198-206

Larrivee, B. (2000) Transforming teaching practice: Becoming the critically reflective teacher. Reflective Practice, 1(3), 293-307, DOI: $10.1080 / 713693162$

Leach, T. (2018). Democracy in the classroom. Power and Education, 10 (2), 181-194

Leavitt, A. (2013). Teaching English language learners in the mainstream classroom: The methods teachers use. The Researcher, 25(1), 79-93.

Liakopoulou, M. (2011). Teachers' Pedagogical Competence as a Prerequisite for Entering the Profession. European Journal of Education, 46(4). 474-488

Livingston, K. (2017). The complexity of learning and teaching: challenges for teacher education, European Journal of Teacher Education, 40 (2), 141-143,

DOI: $10.1080 / 02619768.2017 .1296535$

Louws, M. L., Veen, K. V., Meirink, J. A., \& Driel, J. H. V. (2017). Teachers' professional learning goals in relation to teaching experience. European Journal of Teacher Education, 40(4), 487-504. https://doi.org/10.1080/02619768.201 7.1342241

Lupton, R., \& Hempel-Jorgensen, A. (2012). The importance of teaching: pedagogical constraints and possibilities in working-class schools. Journal of Education Policy, 27 (5), 601-620, DOI: $10.1080 / 02680939.2012 .710016$

Maden, M. (2001). Success against the odds five years on: Revisiting effective 
schools in disadvantaged areas. ed. London: Routledge.

McKay, S. L. (2006). Researching second language classroom. Mahwah, New Jersey, London. LEA

Mills, C., \& Gale, T. (2009). Schooling in disadvantaged communities: Playing the game from the back of the field. New York, NY: Springer.

Moore, A. (2000). Teaching and learning: Pedagogy, curriculum and culture. London \& New York: Routledge

OFSTED (2000). Improving city schools. London: OFSTED

Putney, L, G., \& Frank, C. R. (2008) Looking through ethnographic eyes at classrooms acting as cultures. Ethnography and Education, 3(2), 211-228.

Rashid, R. A. (2018). Dialogic reflection for professional development through conversations on a social networking site. Reflective Practice, 19(1), 105117 ,

DOI: 10.1080/14623943.2017.1379385

Ridnouer, K. (2006). Managing your classroom with heart: A guide for nurturing adolescent learners.

Alexandria, Virginia USA:

Association for Supervision and Curriculum Development

Shindler, J. (2010). Transformative classroom management: Positive strategies to engage all students and promote a psychology of success. San Francisco: Jossey-Bass A Wiley Imprint

Silverman, D. (2017). Doing qualitative research. The 5th ed. Los Angeles, London, New Delhi, Sage Publication, 2017.

Silverman, D. (2020). Interpreting qualitative data. The 6th ed. Los Angeles, London, New Delhi, Sage Publication.
Simon A.J. Beausaert , M.S.R Segers \& Danique P.A. Wiltink (2013) The influence of teachers' teaching approaches on students' learning approaches: the student perspective. Educational Research, 55 (1), 1-15, DOI: 10.1080/00131881.2013.767022

Smyth, J., \& McInerney, P. (2007). Teachers in the middle: Reclaiming the wasteland of the adolescent years of schooling. New York, NY: Peter Lang Publishing.

Soini, T., Pietarinen, J. \& Pyhältö, K. (2016) What if teachers learn in the classroom? Teacher Development, 20(3), 380-397, DOI: 10.1080/13664530.2016.1149511

Stolle, E. P. \& Frambaugh-Kritzer, C.(2014). Putting professionalism back into teaching: Secondary preservice and in-service teachers engaging in interdisciplinary unit planning. Action in Teacher Education, 36(1), 61-75, DOI: $10.1080 / 01626620.2013 .850123$

Soslau, E., Gallo-Fox, J., and Scantlebury, K. (2019). The Promises and Realities of

Implementing a Coteaching Model of Student Teaching. Journal of Teacher Education, 70(3) 265-279

Suciu, A. I., \& Mata, L. (2011). Pedagogical competences - The key to efficient education. International Online Journal of Educational Sciences, 3(2), 411-423

Tabatabaee-Yazdi, M., Motallebzadeh, K., Ashraf, H., \& Baghaei, P. (2018). Continuing professional development strategies: A model for the Iranian EFL teachers' success. SAGE Open January- March 1-14

Taber, K. S. (2007). Classroom-based research and evidence-based practice: A guide for teachers. London, 
Thousand Oaks: Sage Publication, Ltd.

Tauber, R. T. (2007). Classroom management: Sound theory and effective practice. Fourth Edition. Westport. Praeger

Thomson, P. (2002). Schooling the rust-belt kids: Making the difference in changing times. Stoke-on-Trent: Trentham Books.

Trigwell, K., M., Prosser, P., Ramsden, E., Martin, E. (1998). Improving student learning through a focus on the teaching context. In Improving student learning, edited by C. Rust. Oxford: Oxford Centre for Staff Development.

Trigwell, K., Prosser, M., \& Waterhouse, F. (1999). Relations between teachers' approaches to teaching and students' approaches to learning. Higher Education, 37: 57-70.

Woodward, T. (2001). Planning lessons and courses: Designing sequences of work for the language

classroom.
Cambridge: Cambridge University Press

Vangrieken, K., Meredith, C. E., Packer, T., Kyndt, E. (2017). Teacher communities as a context for professional development: A systematic review. Teaching and Teacher Education, 6,47-59

Yough, M.,Merzdorf, H. E., Fedesco, N. F., \& Cho, H. J. (2019). Flipping the Classroom in Teacher Education: Implications for motivation and Learning. Journal of Teacher Education, 70(5) 410-422

Zlatića, L., Bjekić, D., Marinković, S., Bojović, M. (2014). Development of teacher communication competence. Procedia - Social and Behavioral Sciences 116, 606 610

Zulfikar, T. (2014). Researching my own backyard: inquiries into an ethnographic study, Ethnography and Education, 9(3), 373-386, DOI: 10.1080/17457823.2014.919869 